\title{
ANALISIS PROBLEMATIKA MANAJEMEN INVESTASI WAKAF UANG PADA LEMBAGA WAKAF UANG DI SUMATERA BARAT (Studi Pendekatan Analitical Network Proccess)
}

\author{
Nil Firdaus ${ }^{1}$, Amiur Nuruddin ${ }^{2}$, Fifi Hasmawati ${ }^{3}$ \\ 1 Universitas Islam Negeri Sumatera Utara Medan \\ e-mail: firdausnil22@gmail.com \\ 2 Universitas Islam Negeri Sumatera Utara Medan \\ e-mail: amiur.nuruddin@yahoo.co.id \\ ${ }^{3}$ Universitas Islam Negeri Raden Fatah Palembang, \\ e-mail : fifihasmir@gmail.com.
}

\begin{abstract}
Cash Waqf is an endowment done by a person, group, institution or legal entity in the form of cash where the purpose is for the welfare of the community. This study aims to determine the priority of problems, solutions and stategies of investment management through the Analytical Network. (ANP) approach. The results showed the priority of the problem was Nazhir's professionalism (0.407) risk analysis (0.247) supervision (0.205) and guarantee (0.140) with the rater agreement (W: 0.619). Priority solutions are Nazir's professionalism (0.408) supervision (0.239) risk analysis (0.213) and guarantee solutions (0.138) with rater agreement (W: 0.555). While the strategy priority is cooperation with tungku tigo sajarangan $(0,366)$ public education $(0,324)$ and nazhir coaching $(0,308)$ with rater agreement $(W: 0,111)$.
\end{abstract}

Kata kunci: Analisis problematika, manajemen, investasi wakaf, lembaga wakaf.

W akaf Uang bukanlah hal yang baru dalam Islam walaupun pada awal Islam memang praktek wakaf hanya wakaf dalam bentuk tanah, kebun, sumur ataupun benda lainnya yang bersifat kekal zatnya (selain uang). Namun pada abad ke-2 Hijriah mulai dikenal wakaf dalam bentuk dinar dan dirham (keduanya merupakan alat tukar pada masa itu). Imam az-Zuhri memberikan pandangan bahwa dinar dan dirham boleh diwakafkan. Caranya dengan menjadikan dinar dan dirham itu sebagai sebagai modal usaha (dagang) kemudian menyalurkan keuntungnnya untuk kepentingan masyarakat yang membutuhkan. (Abu as-Su'ud, 1997: 20-21). Dalam prakteknya Wakaf Uang (cash waqf) ini pertama kali digunakan pada masa Utsman di Mesir di akhir abad ke-16 (1555-1823 M). (Cizakca, 2004: 1)

Gagasan Certificate Cash Waqf yang dikemukakan oleh MA Manan dewasa ini menjadi menjadi babak baru perkembangan Wakaf Uang di Dunia Islam (Masyita, 2002: 67) dan merupakan hal yang baru dalam perkembangan perekonomian Islam (Antonio, 2001: 101). Sehingga gagasan ini tumbuh dan berkembang di berbagai negara muslim termasuk di Indonesia. Sebagai pemeluk agama Islam terbesar kedua di dunia (Alamsyah, 2012) keseriusan dalam mengelola Wakaf Uang tidak hanya melalui pemerintah saja (seperti namun juga ditunjukan oleh organisasi/institusi kemasyarakatan melalui lembaga Wakaf Uang seperti Tabung Wakaf, Dompet Dhuafa dan sebagainya walapun tidak 
sepenuhnya mengikuti aturan yang telah ditetapkan dalam Undang-Undang Wakaf. (Hasanah, 2011: 222)

Demikian pula di Sumatera Barat, sebagai wilayah dengan 98\% adalah Muslim mendorong masyarakat mewujudkan institusi dalam mengembangkan Wakaf Uang. Di samping telah terbentuknya Badan Wakaf Indonesia (BWI) Sumatera Barat juga terdapat beberapa institusi lainnya seperti Badan Wakaf Uang Muhammadiyah, Yayasan Wakaf ar-Risalah dan Yayasan Pendidikan Pesantren Sumatera Thawalib Parabek. (Rozalinda, 2015) Kehadiran lembaga wakaf ini tentunya sangat menentukan perkembangan Wakaf Uang di Sumatera Barat dalam mewujudkan kesejahteraan masyarakat.

Menurut Sadeq lembaga wakaf dapat dijadikan instrumen penting untuk mengentaskan kemiskinan secara berkelanjutan. Melalui lembaga ini akan meningkatkan kemampuan orang miskin untuk meningkatkan kondisi ekonomi mereka (Sadeq, 2002: 145). Tentunya untuk mencapai tujuan tersebut lembaga wakaf harus menerapkan manajemen yang baik dan tepat terutama dalam manajemen investasi Wakaf Uang. Wakaf Uang di investasikan pada sector pembiayaan melalui LKS, sector rill maupun sektor lainnya sehingga dapat memberikan keuntungan (hasil). Hasil dari investasi inilah yang didistribusikan kepada masyarakat.

Namun dalam perkembangannya masih terdapat berbagai persoalan dalam manajemen investasi Wakaf Uang pada lembaga Wakaf Uang di Sumatera Barat. Sebagai contoh, keadaan nazhir yang belum profesional dalam melakukan investasi Wakaf Uang. Pengangkatan nazhir wakaf lebih didasarkan pada kepercayaan ataupun ketokohan seseorang dalam masyarakat tanpa mempertimbangkan apakah nazhir tersebut memiliki kemampuan dalam mengembangkan aset wakaf melalui instrument investasi. Disamping itu juga masih rendahnya pengawasan baik oleh pemerintah maupun masyarakat terhadap lembaga wakaf yang ada di Sumatera Barat.

Berdasarkan persoalan di atas, diperlukan suatu kajian dalam menggali Problematika Manajemen Investasi Wakaf Uang di Sumatera Barat. Melalui pendekatan Analitical Network Proccess (ANP) maka yang menjadi rumusan masalah adalah: (1) Apa saja prioritas masalah dalam manajemen investasi lembaga Wakaf Uang di Sumatera Barat (2) Apa saja solusi prioritas manajemen investasi Wakaf Uang di Sumatera Barat dan (3) Bagaimana strategi prioritas dalam manajemen investasi Wakaf Uang di Sumatera Barat.

\section{METODOLOGI PENELITIAN}

Penelitian ini merupakan penelitian kualitatif-kuantitatif yang bertujuan untuk memberikan pandangan yang bersumber dari responden. Data yang digunakan adalah data primer yang didapat dari hasil indepth interview dengan pakar dan praktisi Wakaf Uang di Sumatera Barat yang mengerti dengan permasalahan yang dibahas. Kemudian dilanjutkan dengan pengisian kuisioner dalam bentuk pairwise comparison oleh responden yang berjumlah 9 orang (3 orang pakar, 3 praktisi dan 3 regulator)

Alat analisis yang digunakan adalah metode ANP dengan menggunakan software Super Decision. Analytic Network Process (ANP) merupakan kerangka paling komprehensif untuk analisis keputusan masyarakat, pemerintah dan perusahaan yang tersedia saat ini kepada pembuat keputusan. Hal ini memungkinkan seseorang untuk memasukkan semua 
faktor dan kriteria, nyata dan tidak nyata yang harus diambil untuk membuat keputusan terbaik (Saaty, 2003: 39). Adapun tahapan dalam penelitian ANP adalah:

Fase Pertama yaitu konstruksi model disusun berdasarkan literature review secara teori maupun empiris dan memberikan pertanyaan pada pakar dan praktisi. Kemudian dilakukan indepth interview untuk mengkaji informasi secara lebih dalam untuk memperoleh permasalahan dan solusi.

Fase Kedua Tahap kuantifikasi model dimana hasil kerangka ANP yang telah terbentuk pada fase pertama kemudian disusun pertanyaan. Pertanyaan pada tahapan ini dalam kuesioner ANP berupa pairwise comparison (pembandingan pasangan) antar elemen dalam cluster untuk mengetahui mana diantara keduanya yang lebih besar pengaruhnya (lebih dominan) dan seberapa besar perbedaannya melalui skala numerik 1-9.

Sedangkan Fase Ketiga Analisis Sintesis bertujuan menganalisis data yang telah diinput pada software Super Decision. Hasil Analisis sintesis ini bertujuan untuk menentukan: a. Geometric Mean bertujuan mengetahui hasil penilaian individu dari para responden dan menentukan hasil pendapat pada satu kelompok dilakukan penilaian dengan menghitung geometric mean. Pertanyaan berupa perbandingan (Pairwise comparison) dari responden akan dikombinasikan sehingga membentuk suatu konsensus. Geometric mean merupakan jenis penghitungan rata-rata yang menunjukan tendensi atau nilai tertentu dimana memiliki formula sebagai berikut:

$$
\left(\prod_{i}^{n}=1 a_{1}\right)^{1 / n}=\sqrt[n]{a_{1} a_{2} a_{n}}
$$

b. Rater agreement adalah ukuran yang menunjukan tingkat kesesuaian (persetujuan) para responden (R1-Rn) terhadap suatu masalah dalam satu cluster. Adapun alat yang digunakan untuk mengukur rater agreement adalah Kendall's Coefficient of Concordance $(\mathrm{W} ; 0<\mathrm{W} \leq 1) . \mathrm{W}=1$ menunjukan kesesuaian yang sempurna. Untuk menghitung Kendall's (W), yang pertama adalah dengan memberikan ranking pada setiap jawaban kemudian menjumlahkannya.

$$
R_{1}=\sum_{j}^{m}=1 r_{i, j}
$$

Nilai rata-rata dari total ranking adalah:

$$
R=\frac{1}{2} m(n+1)
$$

Jumlah kuadrat deviasi (S), dihitung dengan formula:

$$
S=\sum_{i}^{n}=1\left(R_{i}-\bar{R}\right)^{2}
$$




\section{PEMBAHASAN}

\section{Konsep Wakaf Uang}

Wakaf Uang merupakan وقف النقود terjemahan dari istilah dalam bahasa Inggrinya dengan Cash Waqf. Istilah Cash Waqf dipopulerkan di Bangladesh oleh M.A Manan. Wakaf Uang (cash waqf) secara definsi adalah menahan sejumlah uang oleh pemberi wakaf, baik individu, perusahaan, lembaga, perusahaan atau organisasi swasta atau publik, dan menyerahkan hasil dari Wakaf Uang secara berterusan untuk kesejahteraan masyarakat. (Mohsin, 2013: 87) Menurut Fatwa Majelis Ulama Indonesia, Wakaf Uang (Cash Wakaf / Waqf al-Nuqu-d) adalah wakaf yang dilakukan seseorang, kelompok orang, lembaga atau badan hukum dalam bentuk uang tunai. (Dewan Syariah Nasional, 2002)

\begin{tabular}{lrr}
\multicolumn{2}{c}{ Mengenai } & kebolehan \\
menjadikan uang & sebagai \\
instrument wakaf & terdapat
\end{tabular} perbedaan pendapat dikalangan ulama. Secara umum dikelompokan menjadi dua bagian yaitu yang tidak membolehkan Wakaf Uang dan yang membolehkan Wakaf Uang. Ulama yang tidak membolehkan Wakaf Uang seperti Abu Hani-fah, Abu Yusu-f, Shafi'iah di salah satu pendapat shahihnya dan salah satu riwayat Hanabilah, semua berpendapat bahwa uang tidak bisa dimasukakan dalam kategori harta wakaf yang dibolehkan.
Mazhab Syafi'i masalah ini memiliki dua pendapat, yang paling kuat adalah hukum pelarangan dengan harta berbentuk dinar dan dirham (emas dan perak), baik dimanfaatkan untuk perhiasan maupun untuk digunakan untuk meraup keuntungan. Begitu pula pandangan salah satu riwayat Hana-biah. (Al-Tsamali, n.d: 9) Kelompok yang membolehkan Wakaf Uang seperti ulama Hanafiyah (Wahbah al-Zuhayli. 1985: 162) Malikiah, salah satu pendapat Sya-fi'iah yang tidak dirajihkan dan salah satu riwayat pendapat Hanabilah (alMawardi. 1994: 379). Ibn 'Abidi-n juga berpandangan bahwa mewakafkan uang adalah sah walaupun secara fisiknya uang tidak bertahan kekal dalam bentuk asal, namun pengekalan uang bisa dilakukan apabila uang tersebut direalisasikan dengan menukarkannya dalam bentuk lain. ('Abidin, 1966: 364)

\section{Manajemen Investasi}

Griffin mendefinisikan manajemen sebagai proses perencanaan dan pengambilan keputusan, pengorganisasian, memimpin dan pengendalian organisasi manusia, keuangan, baik fisik dan informasi sumber daya untuk mencapai tujuan organisasi secara efisien dan efektif (Griffin, 1990: 6)

Definisi manajemen menurut Islam tidak jauh berbeda dengan ilmu ekonomi. Manajemen dianggap sebagai ilmu sekaligus seni 
kepemimpinan. Menurut Ahmad Ibrahim Abu Sinn manajemen dipandang sebagai pengetahuan yang dikumpulkan, disistematis dan diterima berhubungan dengan kebenaran-kebenaran universal tentang manajemen. Dalam tatanan seni manajemen diartikan sebagai kekuatan pribadi yang kreatif ditambah dengan keterampilan dalam pelaksanaan. Manajemen merupakan seni organisator dan pemanfaat bakat manusia. Manajemen juga diartikan sebagai suatu rentetan langkah yang terpadu untuk mengembangkan suatu organisasi sebagai suatu system ekonomi teknis (Sinn, 1981: 22-23)

Sedangkan investasi merupakan penanaman uang atau modal dalam suatu perusahaan atau proyek untuk tujuan memperoleh keuntungan (Departemen Pendidikan Nasional, 2005: 1092). Investasi merupakan penanaman modal untuk satu atau lebih aktiva yang dimiliki dan biasanya berjangka waktu panjang dengan harapan mendapatkan keuntungan dimasa akan dating. (Aziz, 2015: 13) Sehingga manajemen investasi merupakan manajemen professional yang mengelola aset berharga melalui penanaman uang atau modal dengan tujuan memperoleh keuntungan dimasa yang akan datang.

Manajemen investasi dapat dilakukan melalui beberapa sektor di antaranya:

a. Investasi sektor Rill seperti investasi mudharabah, investasi musyarakah, investasi murabahah, investasi muzaraah, investasi Ijarah dan model istibdal (mengganti aset wakaf dari bentuk Wakaf Uang menjadi harta tak bergerak seperti pertokoan, apertemen dan sebagainya) dan model istisna

b. Investasi pada sektor portofolio Keuangan Syariah seperti deposito mudharabah, sukuk, pasar modal syariah. (Rozalinda, 2015: 175)

\section{Penentuan Kriteria, Cluster dan Node Manajemen Investasi Wakaf Uang}

Berdasarkan literature review dari berbagai rujukan kemudian dilakukan indepth interview dengan pakar dan praktisi Wakaf Uang Sumatera Barat yang mengerti dan paham dengan Wakaf Uang sehingga secara umum terbagi dalam beberapa kriteris yaitu kriteria masalah, kriteria solusi dan kriteria strategi. Masing-masing kriteria ini terdiri dari beberapa cluster yaitu

a. Masalah terdiri dari: (profesionalisme nazhir, Analisa Resiko, Pengawasan dan Penjaminan)

b. Solusi terdiri dari: (profesionalisme nazhir, Analisa Resiko, Pengawasan dan Penjaminan

c. Strategi yang terdiri dari: (program pembinaan nazhir, edukasi masyarakat tentang Wakaf Uang kerjasama dengan tungku tigo sajarangan)

Masing-masing Cluster masalah terdiri dari beberapa Node yaitu:

a. Masalah profesionalisme nazhir terdiri dari: (kurangnya kepakaran 
nazhir, masih rendahnya komitmen dan kurang terlaksananya kode etik)

b. Masalah analisa resiko, terdiri dari: (kurangnya analisa kelayakan bisnis, kurangnya analisa pasar, lemahnya monitoring dan kurangnya evaluasi investasi)

c. Masalah pengawasan, terdiri dari: (kurangnya pengawasan pemerintah, belum adanya DPS dan kurangnya pengawasan masyarakat)

d. Masalah penjaminan, terdiri dari: (minimnya hasil investasi untuk jaminan, tidak ada kerjasama dengan lembaga penjamin).

Demikian pula dengan cluster solusi juga terdiri dari beberapa node yaitu:

a. Solusi profesionalisme nazhir, terdiri dari: (meningkatkan kepakaran nazhir, meningkatkan komitmen, melaksanakan kode etik)

b. Solusi analisa resiko, terdiri dari: (memaksimalkan analisa kelayakan bisnis, memaksimalkan analisa pasar, meningkatkan monitoring dan melakukan evaluasi)

c. Solusi pengawasan, terdiri dari: meningkatkan peran pemerintah, membentuk DSN pada lembaga wakaf dan laporan berkala kepada masyarakat)

d. Solusi penjaminan, terdiri dari: (melalui cash collateral dan kerjasama dengan lembaga asuransi syariah
3. Hasil Analisis Sintesis Manajemen Investasi Wakaf Uang

a. Prioritas Masalah Manajemen Investasi

Secara keseluruhan resonden menyatakan bahwa yang menjadi prioritas dalam masalah investasi adalah profesionalisme nazhir dengan nilai $(0,407)$, diikuti oleh analisa resiko $(0,247) \quad$ selanjutnya pengawasan $(0,205)$. Sedangkan cluster penjaminan merupakan prioritas terendah dengan bobot 0,140. Rater agreement responden dengan nilai (W: 0,619) menunjukan tingginya tingkat kesepatan responden dalam menentukan prioritas masalah investasi.

Berdasarkan kelompok responden, regulator menyatakan bahwa permasalahan profesionalisme nazhir merupakan masalah prioritas dengan nilai 0,471 diikuti oleh masalah pengawasan $(0,213)$, masalah analisa resiko 0,208. Sedangkan prioritas terakhir adalah masalah penjaminan dengan nilai $(0,107)$. Hasil tingkat kesepakatan responden (rater agreement) adalah sebesar (W: 0,911) yang menunjukan tingkat kesepakatan yang tinggi diantara responden regulator. Artinya 91\% jawaban responden regulator adalah sepakat dalam menentukan urutan prioritas masalah Manajemen Investasi Wakaf.

Menurut responden pakar permasalahan profesionalisme nazhir merupakan prioritas dengan nilai $(0,454)$ diikuti permasalahan analisa resiko dengan nilai $(0,196)$, kemudian 
permasalahan pengawasan sebesar $(0,183)$ dan prioritas terendah adalah masalah penjaminan dengan nilai $(0,165)$. Hasil rater agreement menunjukan tingkat kesepakatan yang tinggi yaitu dengan nilai (W: 0,777). Artinya sebesar $77 \%$ responden pakar sepakat dalam menentukan prioritas masalah manajemen investasi Wakaf Uang.

Sementara itu menurut praktisi masalah analisa resiko merupakan masalah prioritas nilai $(0,336)$, diikuti oleh masalah profesionalisme nazhir dengan nilai $(0,295)$, kemudian masalah pengawasan $(0,219)$ dan yang menjadi prioritas terendah adalah masalah penjaminan dengan nilai 0,143. Hasil rater agreement menunjukan masih cukup tinggi dengan nilai (W: 0,466). Artinya lebih $46 \%$ jawaban responden sepakat dalam menentukan prioritas masalah manajemen investasi Wakaf Uang di Sumatera Barat. Kesepakatan responden dalam menentukan prioritas ini yaitu hanya (W: 0,466), seperti gambar berikut ini:

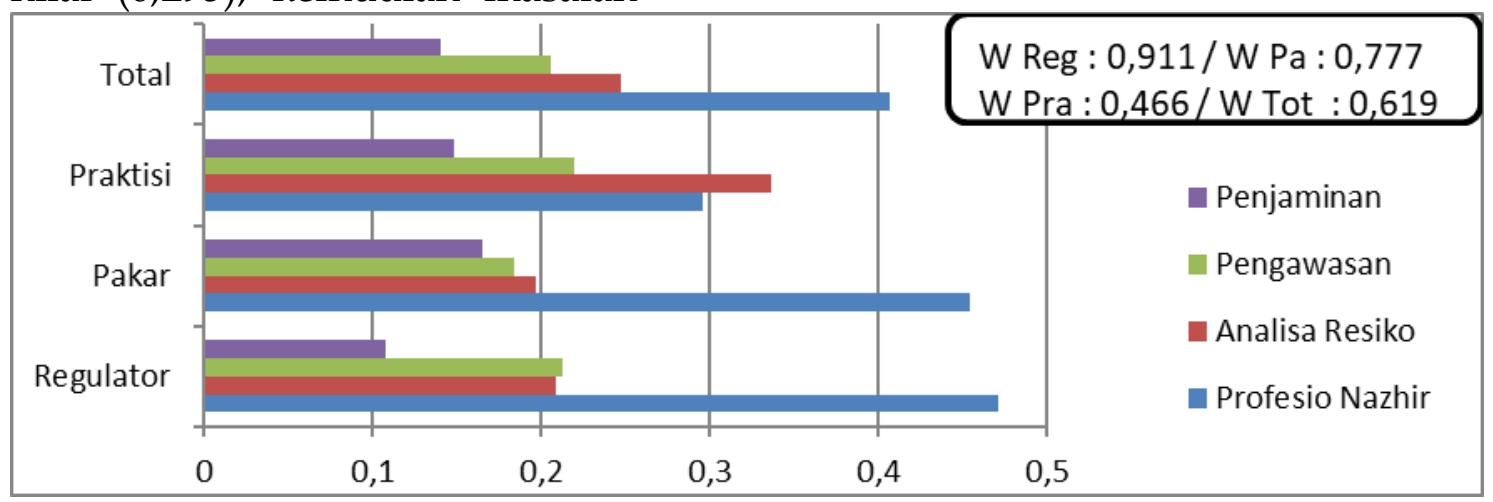

Gambar 1: Prioritas Masalah Investasi Manajemen Wakaf Uang

1) Hasil Prioritas dalam Masalah Profesionalisme Nazhir

Terdapat beberapa node masalah dalam cluster masalah profesionalisme nazhir yaitu (1) Kurangnya kepakaran nazhir wakaf, (2) Kurangnya komitmen nazhir dan (3) Tidak terlaksanannya kode etik nazhir. Hasil analisis menunjukan bahwa menurut keseluruhan responden prioritas utama adalah masalah kurangnya ke- pakaran nazhir dengan nilai $(0,444)$, kemudian kurangya komitmen nazhir dengan niali $(0,303)$ dan terakhir adalah masalah tidak terlaksananya kode etik $(0,251)$. Hasil rater aggrement sebesar (W: 0,261). Bervariasinya jawaban keseluruhan responden menyebabkan rendahnya tingkat kesepakatan keseluruhan responden menentukan prioritas masalah dalam cluster profe- 
sionalisme nazhir, sebagai-

mana pada gambar berikut:

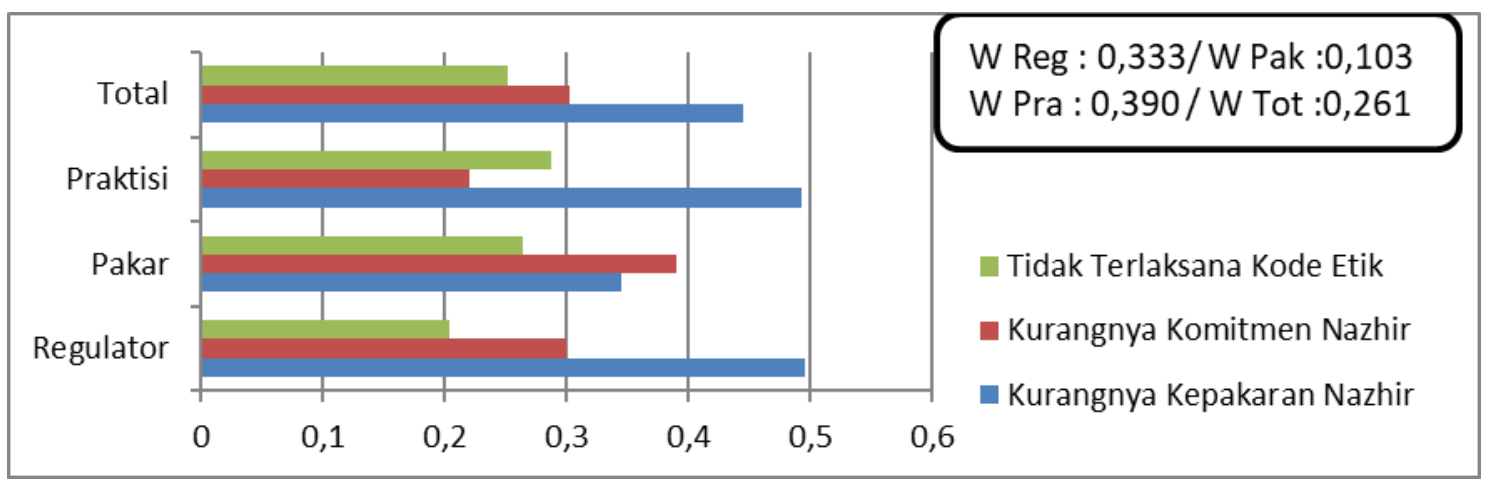

Gambar 2: Prioritas Masalah Manajemen Investasi

2) Prioritas Masalah Analisa Resiko

Keseluruhan responden menyatakan bahwa masalah kurangnya analisa pasar merupakan masalah prioritas dalam masalah analisa resiko dengan nilai $(0,306)$ diikuti masalah kurangnya analisa kelayakan bisnis dengan nilai $(0,295)$ lemahnya monitoring memiliki nilai $(0,218)$. Sedangkan prioritas terendah adalah tidak melakukan evaluasi inves-

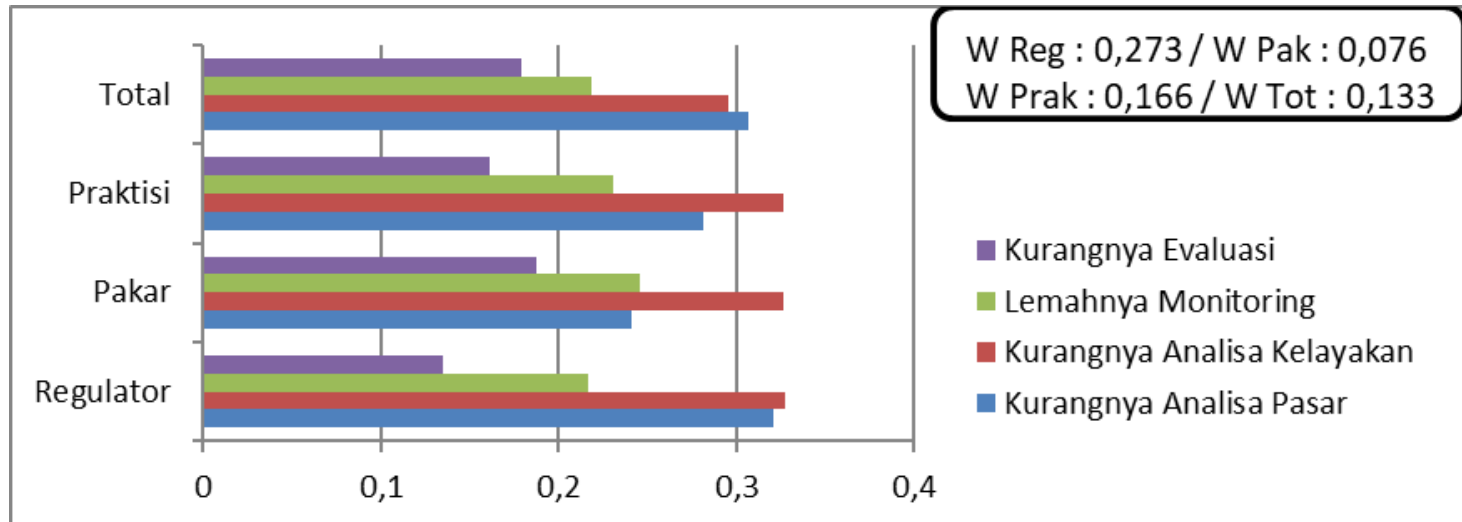

Gambar 3: Prioritas Masalah Analisa Resiko tasi dengan nilai $(0,179)$. Selisih yang tidak jauh ini menunjukan beragamnya jawaban responden sehingga menunjukan rendahnya tingkat kesepakatan seluruh responden dengan nilai rater aggrement (W: 0,133) artinya hanya terdapat 13,3\% kesepakatan di antara responden dalam menentukan prioritas analisa resiko ini. Lebih jelas dapat dilihat pada gambar berikut ini: 
Hasil keseluruhan responden menyatakan kurangnya pengawasan dari pemerintah merupakan masalah prioritas dari masalah pengawasan investasi dengan nilai 0,396, diikuti oleh masalah pengawasan DPS dengan nilai 0,366 dan prioritas terendah adalah pengawasan dari sosial dari masyarakat merupakan prioritas terakhir dengan

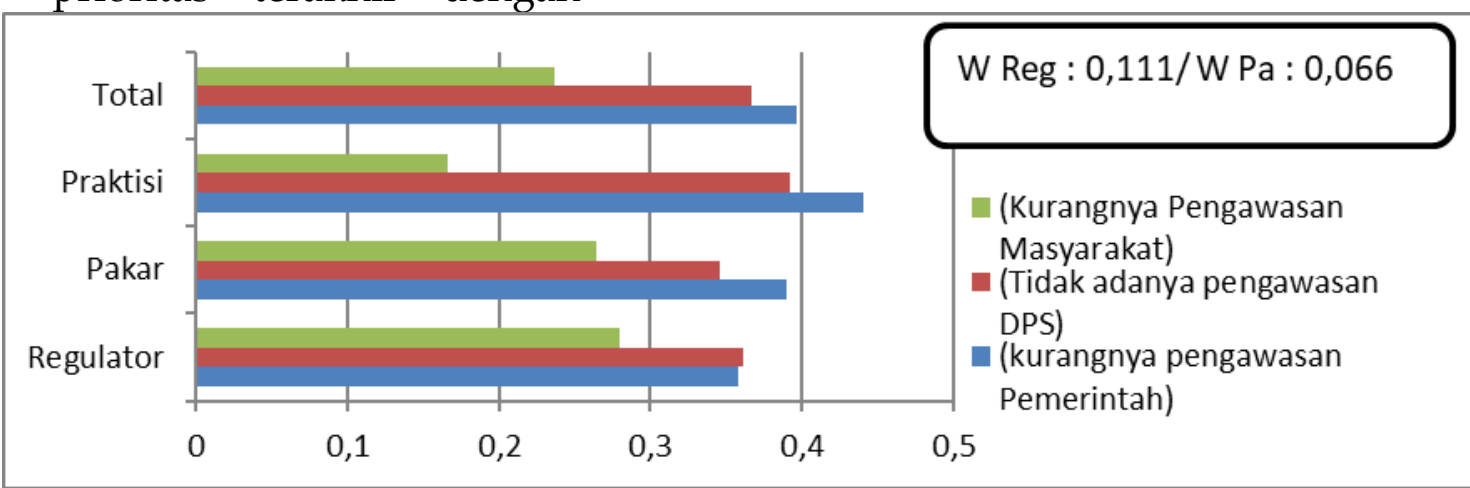

Gambar 4: Prioritas Masalah Pengawasan Investasi Wakaf Uang

4) Prioritas

\section{Penjaminan}

Pentingnya penjaminan dalam investasi dimaksudkan sebagai upaya menghadapi kemungkinan resiko. Sekira-nya dalam investasi mengalami kerugian yang menyebabkan berkurangnya aset Wakaf Uang, maka penjaminan dapat diselesaikan melalui penjaminan. Namun pada lembaga Wakaf Uang di Sumatera Barat terdapat dua masalah dalam penjaminan yaitu minimnya hasil wakaf yang dapat dijadikan sebagai jaminan dan tidak adanya lembaga nilai 0,237. Hal ini menunjukan ketiga-tiga aspek merupakan masalah penting sehingga nilai jawaban seluruh responden bervariasi dengan nilai rater aggrement sebesar (W: 0,182). Lebih jelas dapat dilihat pada gambar berikut ini: 


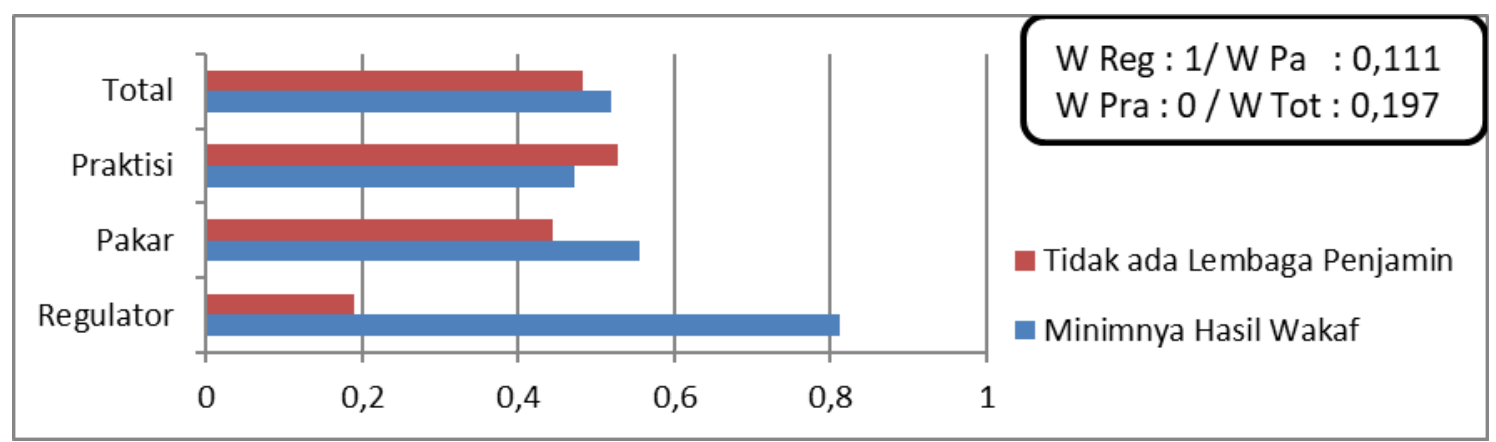

Gambar 5: Prioritas Masalah Penjaminan

\section{b. Prioritas Solusi Manajemen Investasi}

Hasil keseluruhan responden menyatakan solusi prefesionalisme merupakan solusi prioritas dalam solusi investasi dengan nilai $(0,408)$, diikuti oleh solusi pengawasan $(0,239)$, solusi analisa resiko sebesar $(0,213)$ dan prioritas paling akhir adalah solusi penjaminan dengan nilai 0,138. Hasil rater agreement adalah sebesar (W: 0,555) menunjukan tingginya kesepakatan responden dalam menentukan prioritas solusi investasi. Artinya 55\% jawaban responden menyatakan kesepakatan dalam menentukan prioritas solusi Manajemen Investasi Wakaf Uang di Sumatera Barat.

Berdasarkan pandangan kelompok responden didapati bahwa menurut kelompok responden regulator menempatkan solusi profesionalisme nazhir sebagai prioritas utama dengan nilai $(0,454)$, diikuti oleh solusi pengawasan investasi $(0,264)$, solusi analisa resiko bisnis $(0,179)$ dan paling akhir adalah solusi penjaminan investasi dengan nilai $(0,101)$. Nilai rater agreement adalah sebesar (W: 0,466) yang menunjukan cukup tingginya tingkat kesepakatan responden menentukan prioritas solusi masalah investasi.

Demikian juga dengan kelompok responden pakar yang menyatakan profesionalisme nazhir adalah prioritas utama dengan nilai $(0,447)$, diikuti solusi analisa resiko dengan nilai $(0,203)$ solusi penjaminan investasi dengan nilai $(0,178)$ dan paling akhir adalah solusi pengawasan dengan nilai 0,169 . Hasil rater agreement responden pakar adalah tingggi yaitu sebesar (W:0,777), artinya terdapat $77,7 \%$ tingkat kesesuaian jawaban responden.

Walaupun responden praktisi juga berpandangan profesionalisme sebagai prioritas utama namun selisih antara solusi tidak terlalu besar. Secara berurutan prioritas solusi investasi adalah profesionalisme nazhir $(0,322)$, solusi pengawasan $(0,283)$ solusi analisa resiko 
$(0,257)$ dan solusi penjaminan $(0,136)$. Nilai rater agreement sebesar (W: 0,377) yang menunjukan rendahnya kesepakatan antar responden

Gambar 6 : Prioritas Solusi Manajemen Investasi Wakaf Uang

1) Prioritas Solusi Profesionalisme Nazhir

Solusi profesionalisme nazhir menurut keseluruhan responden menyatakan solusi meningkatkan komitmen nazhir merupakan prioritas utama dengan nilai 0,423 diikuti oleh meningkatkan kepakaran nazhir dengan nilai 0,351 dan terakhir

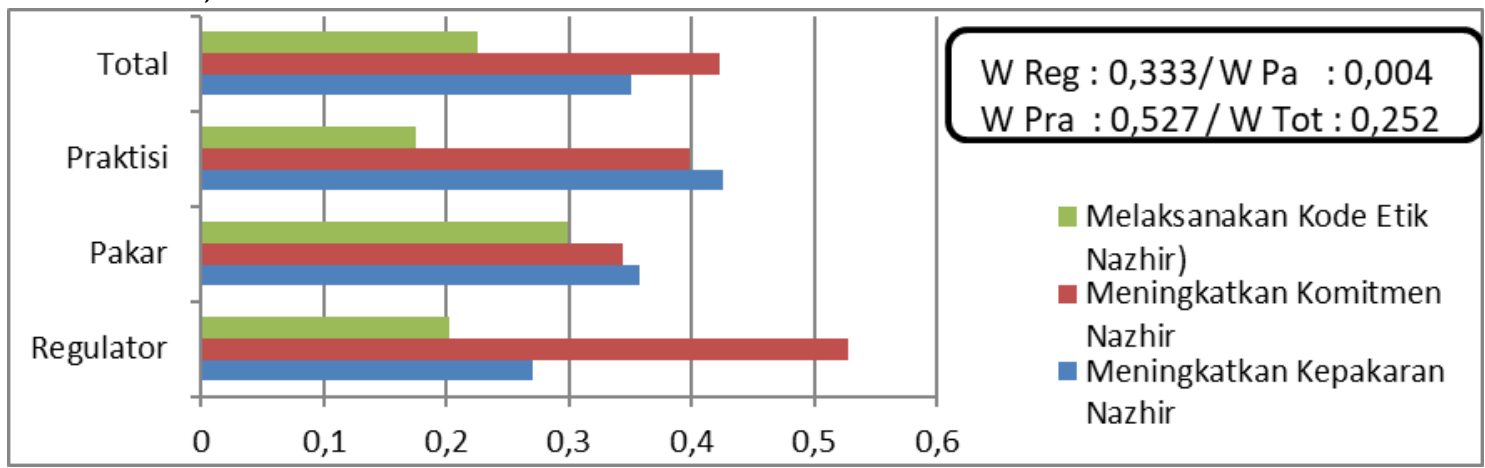

Gambar 7: Prioritas Solusi Cluster Profesionalisme Nazhir

\section{2) Prioritas Solusi Analisa Resiko}

Solusi meningkatkan kemampuan analisa kelayakan merupakan solusi prioritas praktisi dalam menentukan prioritas solusi investasi. Lebih jelas dapat dilihat dalam gambar berikut ini: adalah meningkatkan kode etik dengan nilai 0,225. Hasil nilai rater agreement (W: 0,252) menunjukan rendahnya kesesuaian responden dalam menentukan solusi antar sub profesionalisme nazhir. Lebih jelas dapat dilihat pada gambar 2.7 berikut ini:

Sol Penjaminan

Sol Pengawasan

Sol Profesio Nazhir) 
analisa pasar dengan nilai 0,287 , kemudian melakukan monitoring dengan nilai 0,214 dan prioritas terakhir adalah melakukan evaluasi dengan nilai 0,144. Hasil nilai kesepakatan responden menunjukan beragamnya jawaban sehingga nilai rater agreement hanya (W: 0,251) seperti gambar 2.8 berikut ini:

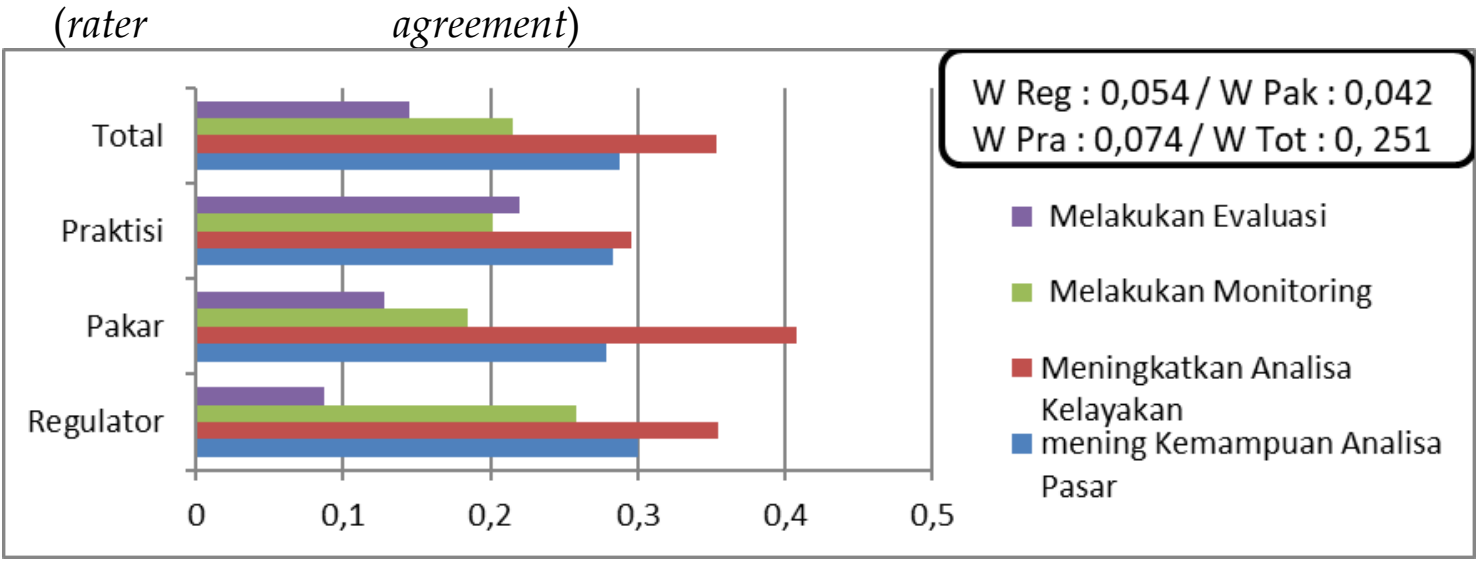

Gambar 8 Prioritas Solusi Cluster Analisa Resiko

3) Prioritas Solusi Pengawasan Investasi

Kajian yang dilakukan oleh Ahmad Syafiq menyatakan pentingnya pengawasan terhadap lembaga zakat. Pengawasan terhadap lembaga pengelola zakat merupakan kewajiban bersama antara pemerintah, dewan pengawas, maupun masyarakat. Peran aktif masyarakat dalam melakukan pengawasan masyarakat akan membuat lembaga pengelola zakat semakin akuntabel dan profesional, sehingga diharapkan masyarakat dapat ikut melakukan peran aktif dalam pengawasan bagi lembaga pengelola zakat (Ahmad Syafiq. 2016: 38) Tentunya pengawasan pada lembaga zakat ini sesuai sekiranya diterapkan pada lembaga pengelola wakaf karena sama-sama lembaga nirlaba.

Meningkatkan peran pemerintah merupakan prioritas utama dalam solusi pengawasan menurut seluruh responden dengan nilai $(0,457)$ diikuti laporan ke masyarakat secara berkala melalui media dengan nilai $(0,295)$. Sedangkan prioritas terakhir adalah membentuk Dewan Pengawas Syariah (DPS) pada lembaga wakaf dengan nilai $(0,246)$ Hasil rater agreement sebesar (W: 0,249) menunjukan bervariasinya jawaban responden sehingga nilai kesesuaian responden rendah. Artinya hanya terdapat $24 \%$ tingkat kesepakatan responden 


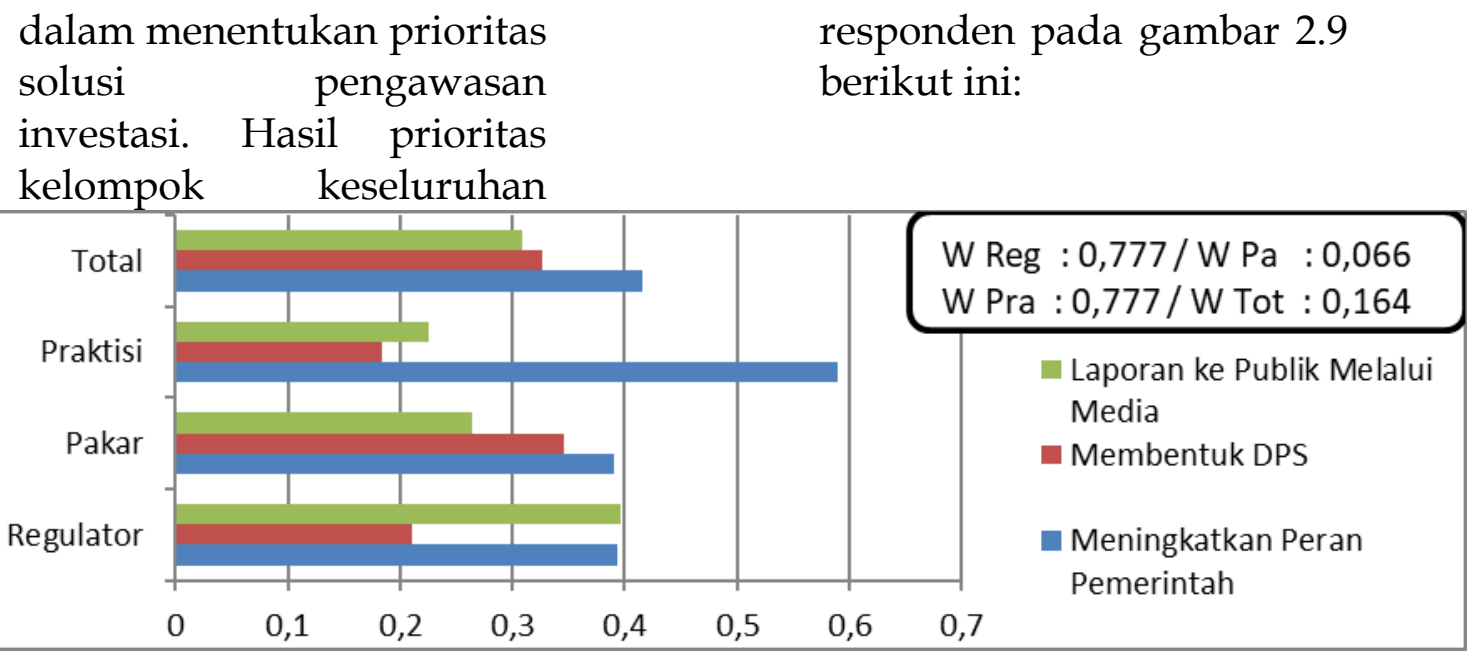

Gambar 9 : Prioritas Solusi Cluster Pengawasan Investasi

\section{4) Prioritas Solusi Penjaminan}

Solusi Penjaminan terhadap aset wakaf ketika di investasikan dapat dilakukan melalui dua cara yaitu menahan hasil wakaf kemudian menjadikan hasil wakaf sebagai jaminan (cash collateral) dan melakukan kerjasama dengan lembaga asuransi. Berdasarkan kedua solusi ini, menurut keseluruhan responden prioritas utama adalah menjadikan hasil wakaf sebagai jaminan dengan cara meningkatkan hasil wakaf (cash collateral) dengan nilai $(0,518)$.

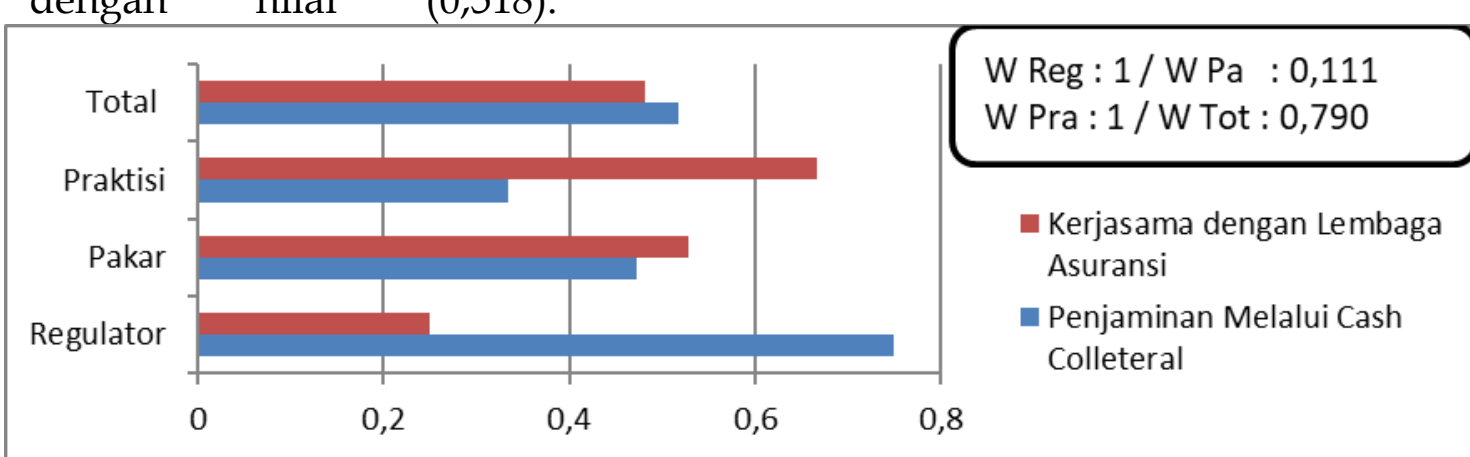

Gambar 10: Prioritas Solusi Cluster Penjaminan Investasi Aset Wakaf
Sedangkan kerjasama dengan lembaga asuransi memiliki nilai 0,481 . Perbedaan hasil dengan selisih yang kecil ini menunjukan kedua-dua node merupakan aspek penting sebagai solusi dalam penjaminan investasi aset wakaf sehingga menyebabkan beragamnya pandangan responden dengan nilai rater agreement rendah yaitu sebesar (W: 0,111). Gambar berikut ini memaparkan prioritas solusi penjaminan menurut keseluruhan responden: 
c. Prioritas Strategi Manajemen Investasi

Hasil analysis terhadap pandangan keseluruhan responden maka didapati prioritas strategi manajemen investasi kerjasama dengan tungku tigo sajarangan merupakan prioritas utama dengan nilai $(0,366)$, diikuti edukasi masyarakat tentang Wakaf Uang dengan nilai $(0,324)$. Sedangkan pembinaan nazhir merupakan prioritas terakhir dengan nilai $(0,308)$. Selisih nilai prioritas yang tidak besar ini menunjukan ketiga-tiga aspek merupakan strategi penting sehingga penilaian responden jadi beragam dengan argument masing-masing sehingga rendahnya nilai rater agreement hanya sebesar (W: 0,111)

Berdasarkan prioritas ini terlihat pentingnya faktor eksternal terutama dalam pengawasan investasi aset Wakaf Uang. Peran pemerintah maupun masyarakat untuk terlibat secara aktif dalam mencapai tujuan wakaf adalah pada aspek pengawasan melalui laporan kegiatan investasi secara berkala. Melalui peran pemerintah dan masyarakat ini akan mendorong para nazhir menjalankan amanah dari masyarakat dengan sebaiknya.
Apabila dilihat dari kelompok responden maka didapati hasil bahwa responden regulator menyatakan prioritas utama adalah kerjasama dengan tungku tigo sajarangan, dengan nilai $(0,408)$ diikuti pembinaan nazhir dengan nilai $(0,301)$ dan prioritas terakhir adalah edukasi masyarakat dengan nilai (0,290). Hasil rater agreement menyatakan rendahnya kesepakatan diantara responden dengan nilai (W: 0111). Responden pakar lebih menyoroti edukasi masyarakat sebagai prioritas utama dengan nilai $(0,380)$ diikuti strategi pembinaan nazhir dan mauquf alaih dengan nilai $(0,340)$ dan kerjasama dengan tungku tigo sajarangan, merupakan prioritas strategi terendah dengan nilai $(0,278)$. Hasil ratet agreement adalah sangat rendah dengan nilai (W: 0). Sedangkan responden praktisi lebih menilai kerjasama dengan tungku tigo sajarangan sebagai prioritas dengan nilai 0,458 diikuti oleh strategi pembinaan nazhir dengan nilai 0,353 dan prioritas strategi terakhir adalah edukasi masyarakat dengan nilai 0,336. Hasil rater agreement juga sangat rendah yaitu dengan nilai (W: 0,006). Lebih jelas dapat dilihat pada gambar berikut ini: 


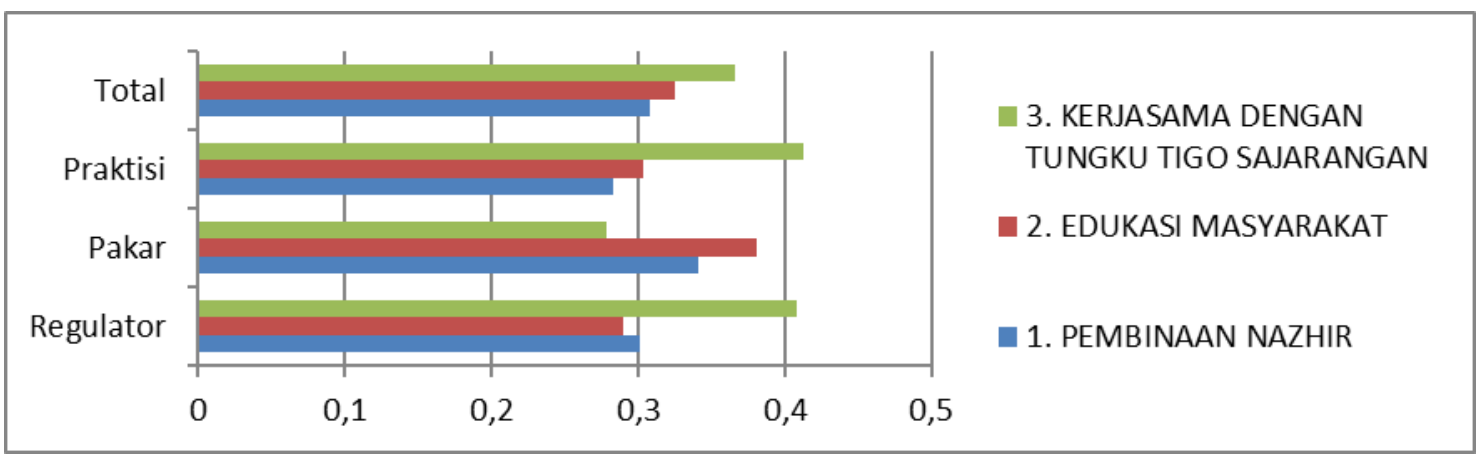

Gambar 11: Prioritas Strategi Manajemen Investasi Wakaf Uang

\section{PENUTUP}

\section{Kesimpulan}

Hasil kajian menunjukan bahwa masalah yang paling prioritas dalam manajemen investasi aset wakaf adalah aspek profesionalisme nazhir dengan nilai $(0,407)$, diikuti oleh analisa resiko $(0,247)$ selanjutnya pengawasan $(0,205)$. Sedangkan cluster penjaminan merupakan prioritas terendah dengan nilai $(0,140)$. Rater agreement responden dengan nilai (W: 0,619).

Sedangkan solusi terhadap permasalahan manajemen investasi adalah solusi prefesionalisme merupakan solusi prioritas dalam solusi investasi dengan nilai $(0,408)$, diikuti oleh solusi pengawasan $(0,239)$, solusi analisa resiko sebesar $(0,213)$ dan prioritas paling akhir adalah solusi penjaminan dengan nilai 0,138. Hasil rater agreement adalah sebesar (W: 0,555)

Berdasarkan solusi maka dihasilkan beberapa strategi dalam manajemen investasi. Aspek yang menjadi prioritas strategi adalah kerjasama dengan tungku tigo sajarangan dengan nilai $(0,366)$, diikuti edukasi masyarakat tentang Wakaf Uang dengan nilai $(0,324)$.
Sedangkan pembinaan nazhir merupakan prioritas terakhir dengan nilai $(0,308)$. Nilai rater agreement sebesar (W: 0,111)

\section{Saran}

a. Pentingnya kesadaran dalam menjalankan amanah dari umat terutama bagi nazhir wakaf sehingga menumbuhkan komitmen dan keseriusan dalam memberdayakan aset wakaf

b. Pentingnya peningkatan kompetensi nazhir wakaf melalui program pembinaan oleh pemerintah

c. Variabel dalam kajian ini masih bersifat umum dan lebih dikondisikan pada keadaan lembaga Wakaf Uang di Sumatera Barat. Sehingga perlu dilakukan kajian lebih lanjut.

\section{DAFTAR KEPUSTAKAAN}

'Abidin, I. (1966). Hāshiyah Rad alMukhtār 'ala al-Dūr al-Mukhtār (edisi ke2,). Dār al-Fik.

Abu as-Su'ud, M. (1997). Risalatu fi Jawā̄i al-Waqfi an-Nuqued. Beirut: Dar Ibn-Hazm. 
Alamsyah, Halim. (2012). Perkembangan dan Prospek perbankan syariah di Indonesia: Tantangan dalam menyonsong MEA 2015, makalah ilmiah Ikatan Ahli Ekonomi Islam (IAEI), milad ke18 IAEI, 13 April.

Al-Tsamali, A. bin M. (n.d.). Waqfu al-Nuquid: Hukmuhu, Tarikhuhu wa aghräduhu, ahamiyatuhu almu'asyirah, Istimaruhu. Makkah: t.p.

Antonio, M. S. (2001). Bank Syari'ah: Dari Teori ke Praktik. Jakarta: Gema Insani Press.

Aziz, M. (2015). Manajemen Investasi Syariah. Yogyakarta: Deepublish.

Cizakca, M. (2004). Ottoman Cash Waqf Revisited: The Case of Bursa 1555-1823. United Kingdom: FSTC.

Departemen Pendidikan Nasional. (2005). Kamus Besar Bahasa Indonesia (edisi ke 3). Jakarta: Balai Pustaka.

Griffin, R. W. (1990). Management. Boston: Houghton Mifflin Company.

Hasanah, U. (2011). Cash Waqf And People Economic Empowerment in Indonesia. Economic and Finance in Indonsia, 59(2).
Masyita, D. (2002). Sertifikat Wakaf Tunai Sebagai Salah Satu Instrument alternative Pengentasan Kemiskinan di Indonesia. Usahawan, XXXI(9).

Mohsin, M. I. A. (2013). Financing Through Cash-Waqf: a Revitalization to Finance Different Needs. Islamic and Middle Eastern Finance and Management, 6(4).

Rozalinda. (2015). Manajemen Wakaf Produktif. Jakarta: PT Raja Grafindo Persada.

Saaty, R. W. (2003). The Analitical hirarci Procces for Decision Making and The Analilical Network Proccess (ANP) for Decision Mekaing with Dependence and Feddback. University of Pittsburgh: Creative Decisions Foundation.

Sadeq, A. H. M. (2002). Waqf, Pertual Charity and Poverty Alleviation. International Journal of Social Economic, 29(1/2).

Sinn, A. I. A. (1981). al-Idarah fi alIslam. Dubai: al-Matba'ah alAshriyah. 
